\title{
Seyahat maliyeti yöntemiyle Ankara ilinde orman içi rekreasyon alanlarına yönelik bölgesel talebin tahmini
}

\author{
Güven KAYA (Orcid: 0000-0001-9769-3023) ${ }^{* 1}$, Kenan OK (Orcid: 0000-0002-0292-6152) \\ Tuncay PORSUK (Orcid: 0000-0002-0931-3236) ${ }^{1}$, Tuğba DENIZ (Orcid: 0000-0002-0114-8790) ${ }^{2}$, \\ Murat ÇETINER (Orcid: 0000-0001-9352-1849) ${ }^{3}$ \\ ${ }^{1}$ İç Anadolu Ormancılık Araștırma Enstitüsü Müdürlüğü, ANKARA \\ 2 İstanbul Üniversitesi, Orman Fakültesi, İSTANBUL \\ ${ }^{3}$ Orman Ağaçları ve Tohumları Islah Araştırma Enstitüsü Müdürlüğü, ANKARA \\ *Sorumlu yazar/Corresponding author: guvenkaya@ogm.gov.tr, Geliş tarihi/Received: 04.12.2017, Kabul tarihi/Accepted: 19.12.2017
}

$\ddot{\mathbf{O z}}$

$\mathrm{Bu}$ araştırma, seyahat maliyeti yaklaşımı kullanılarak türetilecek bir bölgesel rekreasyonel talep fonksiyonu yardımıyla rekreasyon talebini nicel olarak ölçmeyi ve talebi etkileyen değişkenleri belirlemeyi amaçlamıştır. Rekreasyonel ikame ilişkilerinin incelenebileceği mesire yerleri, tabiat parkları ve milli park gibi orman içi rekreasyonel alanlarla, orman dışı pek çok açık hava rekreasyonel fırsat alanı bulunan Ankara ili, çalışma alanı olarak seçilmiştir. Araştırma alanı Ankara ilindeki biri milli park, beşi tabiat park1, yedisi mesire yeri, üçü kent ormanı olmak üzere 16 orman içi rekreasyon sahası ile ikame yerlerini kapsamaktadır. Araştırma verileri, aktüel ve potansiyel ziyaretçilere uygulanan anketlerden elde edilmiştir. Ana etkinliğin piknik olduğu rekreasyon etkinlikleri için, bölgesel seyahat maliyeti yaklaşımına dayalı olarak ve çoklu regresyon analizleriyle iki bölgesel talep fonksiyonu tahmin edilmiştir. Talep fonksiyonlarındaki seyahat maliyeti değişkeninde kuramsal artışlar oluşturularak ikinci aşama talep eğrileri çizilmiştir. Aktüel ve potansiyel ziyaretçilerden elde edilen tüm verilerle oluşturulan talep fonksiyonu dikkate alındığında; 0-503 TL aralığında seyahat maliyeti artışının elde edilebilecek gelir düzeyini artırdığı, bu aralıkta hesaplanan elastikiyet değerinin 0,01 ile 0,75 arasında değiştiği görülmüştür. Ayrıca alanların statüsünün, rekreasyon potansiyelinin, ikame alanın uzaklığının, tesis yeterliliğine yönelik inançların ve alışkanlıkların rekreasyon talebini pozitif etkilediği; buna karşın daha çeşitli etkinlik fırsatları sağlayan, yöresel yemekler için tercih edilen, ikame alanlarda daha çok etkinlik fırsatı olan alanların daha az ziyaret edildiği belirlenmiștir. Araştırmada farklı rekreasyonel alanlar arasında bir ikame etkisinin olduğu kanıtlanmıştır.

Anahtar Kelimeler: Orman içi rekreasyon, bölgesel talep, seyahat maliyeti, rekreasyonel ikame, talep değişkenleri

\section{Estimating regional recreational demand for forest recreation sites with travel cost method in Ankara province}

\begin{abstract}
This research aimed to quantify the regional forest recreation demand and to determine the variables affecting the recreation demand using the regional travel cost approach. Ankara province, which has forest recreation areas such as national parks, nature parks, picnic areas, urban forests and many other outdoor recreation sites in terms of substitution relations, was selected as study area. The research covers 16 forest recreation sites, including one national park, five nature parks, seven picnic areas, three urban forests, and other substitute recreation sites. The main research data were collected by on-site and off-site surveys. Two regional demand functions based on the regional travel cost approach were estimated for forest recreation activities, mainly picnicking, with multiple regression analysis. Then second-stage demand curve was drawn with hypothetical increases in the travel costs by using the regional recreation demand functions. This curve formed using the data obtained from all the users shows that the travel cost increasing up to $€ 503$ has positive effects on revenues from the forest recreation sites as the arc elasticity values in this range are between 0.01 and 0.75 . Moreover, it was found that the conservation status and recreational potential of the areas, distance of the substitution area, beliefs about facility sufficiency and habits of visitors affect recreational demand positively. However, it was found out that areas providing more and various activity opportunities, preferred for local dishes and having substitute areas with more activity opportunities have been less visited. Substitutional relation among recreational sites was proven in the research.
\end{abstract}

Keywords: Forest recreation, regional demand, travel cost, recreational substitution, demand variables

To cite this article (Atıf): KAYA, G, OK, K, PORSUK, T, DENIZ, T, ÇETİNER, M . (2018). Seyahat maliyeti yöntemiyle Ankara ilinde orman içi rekreasyon alanlarına yönelik bölgesel talebin tahmini. Ormancılık Araștırma Dergisi, 5 (1), 15-30.

DOI: 10.17568/ogmoad.361810 


\section{Giriş}

Sürdürülebilir orman kaynakları yönetimi, rekreasyon veya diğer tüm orman işlevlerinde, faydalanıcının talepleri, kaynağın nitelikleri ve potansiyeli hakkında, öncelikle bilgi sahibi olmayı, ardından bu bilgileri kullanmayı gerektirir. $\mathrm{Bu}$ gereklilik, planlama, finansman ve pazarlama gibi yönetim işlevleri açısından daha belirgindir. Çok yönlü faydalanma ilkesine uygun bir işlevsel tahsis yapılabilmesi, finansman için gerekli kullanım bedellerinin hesaplanabilmesi için; ormanların mevcut ve potansiyel rekreasyon arz ve talebinin nitelik ve nicelik olarak ortaya konması, elde edilebilecek faydanın büyüklüklerinin ölçülmesi gereklidir. İlter ve Ok (2012)'un belirttiği gibi, müşterilerin (muhatapların) kimler olduğu, neleri, neden, ne kadar ve nasıl satın aldıkları sorularının yanıtlarına odaklanabilmiș bir yönetim anlayıșına geçmek gerekmektedir. Bu sorular aslında talep araştırmalarının konusudur ve yöneticilere; kullanıcıların rekreasyon davranışlarını tahmin ederek yeni rekreasyon alanlarının tesisi, mevcut alanların talepler doğrultusunda düzenlenmesi kararlarını almalarında destek sağlamaktadır.

Türkiye'de orman içi rekreasyon alanlarının büyük bölümü Orman Genel Müdürlüğü (OGM) ve Doğa Koruma ve Milli Parklar Genel Müdürlüğü (DKMP) tarafından yönetilmektedir. 2015 yılı verilerine göre (OGM, 2016), 1.444 mesire yeri (26.185 ha) vardır. DKMP'nin sorumluluğundaki milli parkların sayısı 40'a (828.614 ha) ulaşırken, tabiat parklarının sayısı 204'e (99.393,54 ha) çıkmıştır (OSB, 2016). Cumhuriyet dönemi boyunca rekreasyon taleplerinin arttığ 1 kabul edilerek, rekreasyon alanları, bir başka deyişle, arzı artırılmıştır. Ancak, arz-talep dengesi incelenmeden, yerel veya bölgesel talep farkl1lıkları dikkate alınmadan, sürekli arzı yükselten bir yaklaşım doğru değildir. Bu kapsamda, Türkiye ormanlarındaki açık hava rekreasyonu hizmet talebinin halen arzdan fazla olduğu varsayılmakta, sürekli ve her yerde yeni alanlar tesis edilmektedir.

$\mathrm{Bu}$ kapsamda kent ormanlarının sayısı, 2015 yılı itibariyle 133'e (10.315 ha) ulaşmıştır (OGM, 2016). 2005-2007 yılları arasında OGM'ye bağlı orman içi mesire yerleri sayısında yıllık \%60'a, toplam büyüklüğünde ise \%308'e varan artışlar meydana gelirken (OGM, 2016), 2011 yılından itibaren alan artı̧̧ oranları, önceki yıllardaki gibi \%10’un altına gerilemiş, hatta 2013 yılından sonra, eksi değerlere düşmeye başlamıştır. OGM 2014 yılı faaliyet raporuna (OGM, 2014a) göre, 9'u kent orman1, 73 orman içi rekreasyon alanı ilk kez kurulurken, 10'u kent ormanı, 157 rekreasyon alanının kurulu- şu iptal edilmiştir. Buna karşın, kent ormanı veya mesire alanı yapılacak yerdeki talep düzeyinin ne olduğu, hedeflenen rekreasyonel tesis ile ne kadarlık ve hangi tipte bir rekreasyonel talebe yanıt verileceğine yönelik somut araştırmaların varlığı bilinmemektedir. OGM'ye devredilen ve devredilmeyen mesire yerlerinin sunduğu hizmetler ve bunlara yönelik toplumsal talebin farkl1lıklarına yönelik analizlerin eksikliği, verilen kararların etkinliğini sorgulamayı engellemektedir. Bütün bunlar göstermektedir ki, rekreasyonel olanakları artıran tesisleri açma, kapama, statüsünü değiştirme gibi kararların, dene-gör yaklaşımından çıkıp, talep analizlerine dayalı ormancılık uygulamaları haline döndürülmesi gereklidir.

İkinci Dünya Savaşı sonrası toplumun artan rekreasyon talebinin baskısıyla, Amerika Birleşik Devletleri'nde (ABD) orman kaynaklarının sağladığ1 açık hava rekreasyon hizmetlerine yönelik talep araştırmaları çoğalmıştır. ABD'de 1960 yılında çıkarılan Çok Yönlü Faydalanma ve Sürdürülebilir Hâsıla Kanunu, bir yandan ormancılık mesleğine çok yönlü faydalanma ilkesini kazandırırken, diğer yandan çok boyutlu sayısal analizleri içeren araştırma yöntemlerinin kullanımını teşvik etmiş, kaynak yöneticilerini araştırmalara dayalı tahminleri dikkate alan uygulamalar konusunda desteklemiştir. $\mathrm{Bu}$ anlayış zamanla yaygınlaşmış ve örneğin 1974 yılında ABD'de kabul edilen Orman ve Mera Yenilenebilir Kaynaklar Planlama Kanunu ile sorumlu kurum olarak Orman Servisinin, açık hava rekreasyonu dahil, yenilenebilir kaynaklarla ilgili olarak, her on yılda bir ekonomik trendler hakkında bir değerlendirme yapması zorunlu kılınmıştır (English ve ark., 1993). ABD'de yapılan rekreasyon talebi araştırmalarına paralel olarak ekonomik değer tahmin araştırmaları yapılmıştır. Bu durumun temel nedeni, araştırmalarda en çok tercih edilen yöntem olan seyahat maliyeti yönteminin (SMY), hem talebi açıklama, hem değer belirleme amaçlı kullanılabilmesidir.

Nitekim Türkiye Ulusal Ormancılık Programında (2004-2023) da rekreasyon araştırmaları stratejik olarak teşvik edilmiştir (ÇOB, 2004). Ancak idarenin talebinden ziyade, akademik merakla yapılan ve SMY kullanılan orman içi rekreasyon araştırmalarında (Akesen, 1983; Kaya ve ark., 2000; Pak, 2003; Ortaçeşme ve ark., 2002; Gürlük, 2006; Başar, 2007; Özdemir, 2006; Kaya ve ark., 2009) genellikle ekonomik değer tahminine odaklanılmış, maliyet, giriş ücreti, gelir, talep esneklikleri, kalite ve ikame etkisi gibi iktisadi değişkenler çok nadir analiz edilmiştir. ABD'de olduğu gibi, periyodik olarak tekrarlanan, metodolojik temelleri sağlam rekreasyon talebi araştırmaları Türkiye'nin sorum- 
lu kurumlarınca ne talep edilmiş, ne de yapılmıştır.

Türkiye'de yeni rekreasyon tesislerinin açılma veya kapatılmasının yanı sıra, mevcut sahaların yönetim planlarının içereceği etkinliklerin idaresinde de problemler gözlenmektedir. Orman içi rekreasyon alanları arasında, tıpkı iktisadi mallarda görüldügü gibi ikame, rekabet veya tamamlayıcı ilişkiler bulunabilmektedir. O nedenle, tekil araştırmalar yanında, bir bölgedeki tüm rekreasyon alanlarına yönelik kullanıcıların davranışlarını dikkate alan bölgesel rekreasyon talep araştırmalarının yapılması gereklidir.

Türkiye'de mevcut orman içi rekreasyon talebi araştırmalarının genellikle tek bir alan için yapıldığ 1 , birden fazla rekreasyon alanının konu edildiği araştırmalarda da analizin her bir alan için ayrı ayrı gerçekleştirildiği görülmektedir. ABD'de ise rekreasyon talebi araştırmalarında (English ve ark., 1993) bölgesel analizlerin tercih edildiği bilinmektedir. Dünya genelinde de, geniş coğrafi alanlarda rekreasyon talebi ve toplam değerini araştıran çok az çalışmanın olduğu (Lutz ve ark., 2000; GarberYonts, 2005), tek veya küçük alanlı çalışmaların karar verme sürecine sınırlı bilgi sağladığ 1 (Hill ve Courtney, 2006), bu yüzden tüm alanların etkileşiminin ve toplam değerlerin ölçülmesi gerektiği (Heal ve ark., 2005) ifade edilmektedir (Bestard ve Font, 2010).

Bununla birlikte, ziyaretçilerin alınan rekreasyon kararları karşısında gösterebilecekleri olası tutumların da bilinmesi gereklidir. Giriş ücreti talep etmek ve park yerlerinden ücret almak gibi, alan yönetimiyle ilgili kararların, ziyaretçilerce nasıl karşılanacağının öngörülmesine yarayan çalışmalara ihtiyaç bulunmaktadır. Olası ziyaretçi sayıları, rekreasyon giderleri, alan yönetiminin elde edebileceği gelirler üzerinde sağlam tartışmaların yapılabilmesi için, talep analizleri yapılmalı ve elde edilen talep fonksiyonlarının, özellikle fiyat ve gelir esneklikleri ortaya konmalıdır.

Kaynak israfına neden olmadan, Türkiye'de halen $\operatorname{arttığı~varsayılan~rekreasyon~taleplerini~karşıla-~}$ manın gerekliliği, toplumun orman içi rekreasyon alanlarına yönelik aktüel ve potansiyel taleplerinin ve ziyaretçilerin rekreasyon davranışlarının bölgesel düzeyde ölçülmesine yönelik araştırmaların önemini arttırmaktadır.

Yukarıdaki gerekçelerle gerçekleştirilen bu araştırma, seyahat maliyeti yaklaşımı kullanılarak türetilecek bir bölgesel rekreasyonel talep fonksiyonu yardımiyla, rekreasyon talebini nicel olarak ölçmeyi ve talebi etkileyen değişkenleri belirlemeyi amaçlamıştır.

\subsection{Seyahat maliyeti yöntemi}

Harold Hotelling (1947), milli parkların değeri hakkında bilim adamlarının görüşlerine başvuran ABD Milli Parklar Servisi'ne 1947 yılında bir mektup göndererek, bu yöntemin temel düşüncesini ifade etmiştir (Pearce, 2002). Hotelling'in mektubu, Clawson (1959) tarafından geliştirilen seyahat maliyeti yönteminin (SMY) temelini oluşturmuştur. Bölgesel seyahat maliyeti araştırmaları 1980'li yıllarda ABD'de oldukça yaygınlaşmıştır. SMY araştırmalarına; ABD Washington, Oregon ve Idaho eyaletlerine 195 alanda kampçılık, balık tutma, yüzme ve rafting etkinliklerinin (Sutherland, 1983), California Çölü su rezervuarlardaki rekreasyon hizmetlerinin (Ward ve ark., 1996), Colorado eyaletinde yabanil alanlarda rekreasyon hizmetlerinin (Hof ve Loomis, 1983), 86.700 acre büyüklügüundeki bir orman alanında 30 yıllık periyotta odun hammaddesi üretiminin rekreasyon ve ticari amaçlı balık avlama etkinlikleri üzerindeki etkilerinin (Loomis, 1988), ABD Oregon'da 20 avlakta av etkinliklerinin (Shalloof, 1985) ve yine Oregon'da sportif alabalık avının (Abdullah, 1988) ekonomik değerlerini tahmin etmeye yönelik çalışmalar örnek verilebilir. 1990'lı yılların sonlarına doğru ise çok alanlı SMY uygulamalarında daha gelişmiş ekonometrik modellerin kullanılmaya başlandığı görülmektedir. ABD'de bu dönemde; Güney Dakota'da 19 rekreasyon alanında rafting ve kamp yapma etkinliklerine (Piper, 1997), Snake Irmağında sportif balıkçılığa (McKean ve ark., 2001), yine Snake Irmağında kamp yapma, rafting, su kayağ1, yüzme ve piknik etkinliklerine (McKean ve ark., 2005), New Mexico eyaletinde altı su rezervuarında rekreasyon hizmetlerine (Brinegar ve Ward, 2009), Alaska'da 29 yerde rekreasyon amaçlı balıkçılığa (Carson ve ark., 2009) yönelik talep ve ekonomik değer tahmin araştırmaları yapılmıştır. ABD dışında İspanya / Mallorca'da ise 59 orman alanında açık hava rekreasyonunun ekonomik değerini tahmin etmek için özgün bir araştırma (Bestard ve Font, 2010) gerçekleştirilmiştir.

Seyahat Maliyeti Yöntemi (SMY) bir alandaki rekreasyonel etkinliklere ilişkin talep eğrisini türetirken, fiyat yerine seyahat maliyetini vekil olarak kullanır. SMY, "bir rekreasyon alanına yapılan yıllık ziyaret sayısını, ziyaretlerin seyahat maliyetleriyle ters orantıl değiştiği" varsayımından hareket eder (Kaya, 2002). SMY'ye göre, rekreasyon alanının talebi veya ziyaret sayısı (ZS), ziyaretçilerin seyahat maliyeti (SM), geliri (G), rekreasyon alanının kalitesi (AK), ikame rekreasyon alanının kalitesi (İK), demografik ve diğer sosyoekonomik değişkenler (DSE) ve ziyaretçilerin zevk, tercih ve beklentilerinin (ZT) bir fonksiyonudur (Formül 1): 


$$
Z S=f(S M, G, A K, \dot{\mathrm{I}} K, D S E, Z T)
$$

Formül 1 aslında SMY talep fonksiyonunun genel formudur. Uygulamada bireysel-zonal ve tek alanl1-bölgesel (çok alanlı) şeklinde farklı SMY yaklaşımları geliştirilmiştir. Bireysel ve zonal yaklaşımlar arasındaki temel fark; talep birimi olarak bireylerin veya yerleşim yerlerinin (ziyaret orijinlerinin) esas alınması, dolayısıyla talep fonksiyonunda talepçilerle ilgili bağımlı ve bağımsız değişkenlerin seçiminden kaynaklanır. Bireysel yaklaşımda bağımlı değişken, rekreasyon alanının çekim alanında kaldığ 1 kabul edilen yerleşim yerlerinden gelen her bir ziyaretçinin yıllık ziyaret sayısıdır. $\mathrm{Bu}$ yaklaşımda ziyaret sayısını etkileyebildiği düşünülen; gelir, yaş, cinsiyet, meslek, zevk ve tercihler gibi değișkenler için bireysel nitelikler kullanılır.

Zonal yaklaşımda ise rekreasyon alanına uzaklık açısından birbirine yakın ziyaret orijinleri (yerleşim yerleri), zonlar altında gruplandırılır. Zonal yaklaşımda bağımlı değişken, her bir zondan rekreasyon alanına yapılan ziyaretlerin zonların nüfusuna bölünerek elde edilen kişi başına ziyaret sayısı veya katılım oranıdır. Bu tip bir analizde, ziyaretçilerin demografik ve sosyoekonomik nitelikleri ile zevk ve tercih değişkenleri için, her bir zonu yansıtacak ortalama değerler kullanılır.

SMY ile birden fazla rekreasyon alanına yönelik talep fonksiyonu türetilerek, ekonomik değer tahminleri de yapılabilir. Çok alanlı yahut bölgesel yaklaşım olarak bilinen bu yaklaşımda, zonal ve bireysel SMY yaklaşımları kullanılabilir. Bölge ve zon yaklaşımlarını birlikte kullanarak bir SMY yaklaşımı geliştirildiğinde, bağımlı değişken, her bir ziyaret orijininden, her bir rekreasyon alanına yapılan ziyaretlere katılım oranıdır. Loomis ve ark. (1986)'na göre; bölgesel rekreasyon talep modelleri yahut çok alanlı talep modelleri, basit kaynak sorunlarına cevap üretmek açısından, tek alanlı modellere göre daha maliyet etkin ve daha güvenilir değildir. Bununla birlikte, yeni rekreasyon alan1nın tesis edilmesi veya mevcut bir alanın kalitesini iyileştirmekten doğan faydaların değerlendirilmesi gibi yönetsel sorunlar varsa bölgesel yaklaşım tercih edilmelidir.

\subsection{Türkiye'de SMY araștırmaları}

Türkiye'de rekreasyonel talep tahmin yöntemlerinin irdelendiği bilinen ilk yayın Geray'ın (1972) çalışmasıdır. SMY'nin ilk uygulaması ise Akesen (1983) tarafından Fethiye'deki iki orman içi rekreasyon alanında gerçekleştirilmiştir. Çevresel değer belirlemeye yönelik akademik ilgi artışı ile birlikte, 2000 y1lından itibaren SMY kullanılarak bazı araştırmalar yapılmıştır. SMY'nin, Soğuksu Milli
Parkı (Kaya ve ark., 2000), Kurşunlu Şelalesi Tabiat Parkı (Ortaçeşme ve ark., 2002), Trabzon ve Kahramanmaraş'da yedi orman içi rekreasyon alanı (Pak, 2003), Manyas Gölü Kuş Cenneti (Gürlük, 2006), Dilek yarımadası-Büyük Menderes Deltası Milli Parkı (Başar, 2007) ve Beynam orman içi rekreasyon alanında (Özdemir, 2006) piknik başta olmak üzere rekreasyon hizmetlerine ve Bartın'da rekreasyon amaçlı avcılığa (Kaya ve ark., 2009) yönelik araştırmalarda kullanıldığı görülmektedir.

Akesen (1983) dışındaki araştırmalar, rekreasyon hizmetlerinin ekonomik değerinin belirlenmesine yöneliktir ve çoğunda elde edilen veri ve fonksiyonlarla talep analizleri yapma olanağı varken, nadiren (Kaya ve ark., 2000) bu analiz gerçekleştirilmiștir. Ayrıca SMY araştırmalarında, doğal avlaklarda avcılığın ekonomik değerinin araştırıldığ bir çalışma (Kaya ve ark., 2009) dışında, birden fazla alan kapsayanlar da dahil olmak üzere, bölgesel veya çok alanlı yaklaşımın kullanıldığı başka bir SMY araştırması bulunmamaktadır. Üstelik bu araştırmaların talep fonksiyonlarında çalışma alanı veya ikame alanların kalitesine yönelik değişkenler kullanılmamıştır. Bu araştırmalar arasında, türetilen fonksiyonların rekreasyon talebini açıklama düzeyini gösteren belirlilik katsayıları $\left(\mathrm{R}^{2}\right)$ \%93 gibi yüksek değerlere ulaşan çalışmalar (Kaya ve ark., 2000) olduğu gibi; \%4,5 gibi oldukça düşük değerler bulunan araştırmalar (Ortaçeșme ve ark., 2002) da mevcuttur.

\section{Materyal ve Yöntem}

\subsection{Materyal}

DKMP ve OGM'nin araştırma amacına uygun resmi yazışmaları, yayınlanmış ve yayınlanmamış istatistikleri, bölge haritaları, web bilgileri ve broşürleri materyal olarak kullanılmıştır. Araştırma yöntemi ile ilgili yayınlar ise bir diğer araştırma materyalini oluşturmuştur. Bunlara ek olarak, araştırma yönteminin gerektirdiği birincil verileri toplamak üzere, araştırma ekibince aktüel ziyaretçi (alan içi) ve potansiyel ziyaretçi (alan dışı) anket formları üretilmiş ve çalışmanın özgün materyali olarak kullanılmıştır.

\subsection{Araştırmada uygulanan seyahat maliyeti yöntemi yaklaşımı}

Araştırmada ziyaret orijin zonlarının (yerleşim yerlerinin) talep birimi kabul edildiği bölgesel-zonal seyahat maliyeti yaklaşımı ana yöntem olarak kullanılmıștır. Araştırma sürecinde, bir SMY araştırmasının gerektirdiği aşamalar izlenmiştir. $\mathrm{Bu}$ aşamalar ve uygulama biçimleri aşağıda başlıklar halinde verilmiştir. 


\subsubsection{Rekreasyon alanlarının, hedef toplumun ve zonların belirlenmesi}

Araştırma alanı, Ankara ilinde OGM ve DKMP tarafından yönetilen orman içi rekreasyon alanlarını ve bu alanları ikame edebilecek yerlerle sınırland1rılmıştır. Ülke ormanlarının \%1,97'sinin (441.242 ha) yer aldığı Ankara ilinde 2016 yılı itibariyle 2 milli park (MP), 9 tabiat parkı (TP), 15 A, B ve
C tipi mesire yeri ve 7 kent ormanı bulunmaktadır (OSB IX. Bölge Müdürlüğü, 2016; OGM, 2016). Bu alanların bir bölümü aktif olarak kullanılmadığından araştırma kapsamı dışında bırakılmıştır. Araştırmada, Tablol'de listelenen ve Ankara il haritasındaki konumları Şekil 1'de verilen 16 orman içi rekreasyon alanına yönelik talebin tahmin edilmesi hedeflenmiştir.

Tablo 1. Araştırma alanlarının içerdiği rekreasyonel alanlar Table 1. Forest recreation sites in the research area

\begin{tabular}{lllrr}
\hline Alan adı & Statüsü & İlçesi & Alanı (ha) & Ziyaret sayıs1 \\
\hline Soğuksu & Milli park & Kızılcahamam & 1183,00 & 200.000 \\
Aluçdağ1 & Tabiat park1 & Çamlıdere & 90,00 & 20.000 \\
Çamkoru & Tabiat park1 & Çamlıdere & 215,00 & 12.000 \\
Eğriova & Tabiat park1 & Beypazarı & 10,00 & 1.000 \\
Karagöl & Tabiat park1 & Çubuk & 10,79 & 14.000 \\
Sorgun & Tabiat park1 & Güdül & 50,00 & 5.000 \\
Hoşebe & A tipi mesire yeri & Nallıhan & 7,50 & 2.000 \\
Meşelidağ & A tipi mesire yeri & Altındağ & 19,49 & 2.000 \\
Yeşildere & B tipi mesire yeri & Sincan & 7,20 & 7.500 \\
Beynam & C tipi mesire yeri & Bala & 87,38 & 8.000 \\
Karakaya & C tipi mesire yeri & Keçiören & 17,01 & 5.000 \\
Kilıçlar & C tipi mesire yeri & Kahramankazan & 27,66 & 6.000 \\
Uluhan & C tipi mesire yeri & Nallıhan & 2,50 & 1.000 \\
Başkent (Kartaltepe) & D tipi mesire yeri (Kent orman1) & Keçiören & 66,40 & 10.000 \\
Beşikkaya (Altınköy) & D tipi mesire yeri (Kent orman1) & Altındağ & 19,37 & 5.000 \\
Kızılcahamam & D tipi mesire yeri (Kent orman1) & Kizılcahamam & 24,40 & 2.500 \\
\hline Toplam & & & 1837,70 & 301.000 \\
\hline
\end{tabular}

Yukarıda listelenen orman içi rekreasyon alanları dışında kalan, çoklukla ormancılık kurumları d1şındaki birimlerce yönetilen ve ziyaretçilere benzer rekreasyonel firsatlar sunabilen parklar, bahçeler ve diğer açık hava dinlenme alanları araştırmanın ikame alanları olarak kabul edilmiştir.

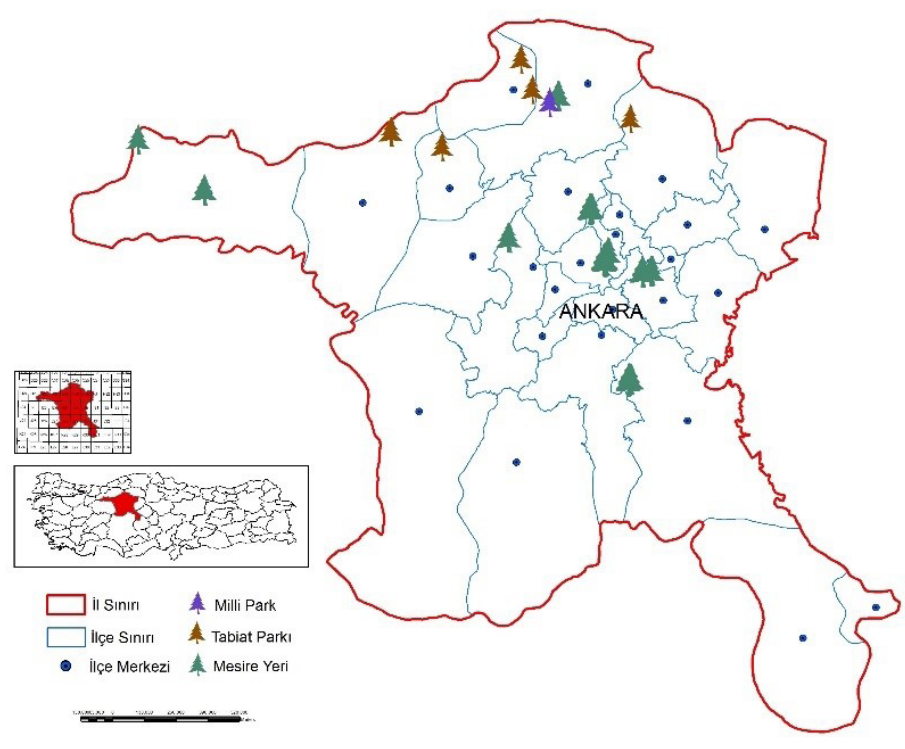

Şekil 1. Ankara ili orman içi rekreasyon alanları haritası

Figure 1. Forest recreation sites in Ankara province 
Bir bölgede yer alan orman içi rekreasyon alanlar1na yönelik talebin, talep üzerinde etkili değişkenlerin sağlıklı tahmin edilmesi için, alan üzerindeki ziyaretçiler kadar, alanları daha önce ziyaret eden, fakat tercihlerini değiştirenlerle, hiç ziyaret etmeyenlerin de talep ve beklentilerinin ölçülmesi gerekir. O nedenle Ankara ilinde yer alan orman içi rekreasyon alanlarının aktüel ve potansiyel ziyaretçileri, araştırmanın hedef toplumu olarak belirlenmiştir. Bu çalışmada; araştırma alanı içerisinde kalan herhangi bir rekreasyon alanında, en az bir rekreasyon etkinliği yapmak üzere fiilen bulunan kişiler aktüel ziyaretçi olarak adlandırılmıştır. Potansiyel ziyaretçi terimi ise araştırma alanı içerisinde kalan bir rekreasyon alanını halen ziyaret etmeyen, fakat daha önce ziyaret etmiş veya etmemiş olmakla birlikte, sürekli yaşadığ 1 alan dikkate alındığında ziyaret etme olasılığı bulunan kişileri tanımlamak için kullanılmıştır. Aktüel ziyaretçilere rekreasyon alanları içerisinde yapılan anketlerle ulaşılırken, potansiyel ziyaretçi görüşmeleri rekreasyon alanları dışında yapılmıştır. Araştırma maliyetleri düşünülerek potansiyel ziyaretçiler Ankara ilinde ikamet eden toplumla sınırlandırılmıştır. $\mathrm{Bu}$ bağlamda Ankara ili ilçeleri birer orijin zonu olarak kabul edilmiştir.

\subsubsection{Rekreasyon talep modeli ve veri gereksinimi}

Zonal yaklaşıma uygun olarak i. orijin zonu (ilçesi) ve j. orman içi rekreasyon alanı için rekreasyon talep modeli Formül 2'deki gibi kurulmuştur:

$$
\operatorname{KATOR}_{i j}=f\left(S M_{i j}, G_{i}, A K_{j}, \dot{I} K_{i j}, D S E_{i}, Z T_{i}\right)
$$

Formül 2'deki modelde bağımlı değişken olan i. ziyaret orijini zonundan j. orman içi rekreasyon alanına ziyaretlere katılım oran1 $\left(K_{\left.A T O R_{i j}\right)}\right)$ i. orijin zonundan (ilçeden) j. rekreasyon alanına ziyaret sayısının $\left(Z S_{i j}\right)$ i. orijin zonunun (ilçenin) nüfusuna $\left(N_{i}\right)$ oranlanmasıyla (Formül 3) elde edilmiştir:

$$
K_{A T O R_{i j}}=Z S_{i j} / N_{i}
$$

Araştırmada seyahat maliyetinin (Formül 4) ise i. zondan $\mathrm{j}$. alana ziyaretlerde ulaşım harcamaları $\left(\mathrm{UH}_{\mathrm{ij}}\right)$, ulaşım süresinin firsat maliyeti $\left(\mathrm{USM}_{\mathrm{ij}}\right)$, alanda rekreasyon etkinliği zamanının firsat maliyeti $\left(\mathrm{RSM}_{\mathrm{ij}}\right)$, j. alana giriş ve/veya otopark ücretinden $\left(\mathrm{GB}_{\mathrm{j}}\right)$ ve alana özgü harcamalardan $\left(\mathrm{AH}_{\mathrm{j}}\right)$ oluştuğu kabul edilmiştir:

$$
S M_{i j}=U H_{i j}+U S M_{i j}+R S M_{i j}+G B_{j}+A H .
$$

Bu seyahat maliyeti kalemleri ayrı değişkenler olarak tasarlanmış, ancak otokorelasyon tehlikesinden sakınmak için, ulaşım harcamaları esas alınmak üzere, diğerleriyle farklı bileşkelerinin türetilmesi öngörülmüştür. Burada temel varsayım olarak; ziyaretçilerin öncelikle ziyaret için gerekli harcamaların bir veya birkaçını ulaşım harcamaları ile toplayarak ödedikleri kabul edilmiştir. Ayrıca seyahat maliyetlerinin kişi başına hesaplanması anlayışı benimsenmiştir. Çok amaçlı ziyaretler dışlanmamış, fakat ziyaretin toplam maliyeti içinde rekreasyon alanına özgü seyahat maliyetleri dikkate alınmıştır.

Ziyaretçilerin özel araç, toplu taşıma, özel turlar veya yaya olarak alana ulaşabilecekleri araç olarak, bisiklet, motosiklet, otomobil, minibüs, otobüs veya cip gibi araçları kullanabilecekleri düşünülmüştür. Özel araçla rekreasyon alanına ulaşanlar için kişi başına ulaşım harcaması Formül 5 ile hesaplanmıştır:

$$
U H_{i j}=U Z_{i j} \times B U M / K S_{i j}
$$

Formül 5'deki $\mathrm{UZ}_{\mathrm{ij}}$, i. orijin zonundan j. alana gidiş-dönüş uzaklığını; BUM, birim ulaşım maliyetini; $\mathrm{KS}_{\mathrm{ij}}$, araç başına kişi sayısını göstermektedir. BUM, 0,30 TL/km olarak kabul edilmiştir. Diğer araçları kullananlar için ise grup büyüklüğünün dikkate alınması veya rapor ettikleri değerlerin kullanılması yaklaşımı benimsenmiştir.

Seyahat maliyeti değişkeninin diğer bileşeni olan zaman maliyetinin $\left(\mathrm{USM}_{\mathrm{ij}}\right.$, ve RSM $_{\mathrm{ij}}$ ) hesabında; Cesario ve Knetsch (1970)'in saatlik ücret oranlarının 1/3'ünün esas alınması önerisi dikkate alınmıştır. Bu hesaplarda hem deneklerin rapor ettikleri değerler, hem de genel istatistiklere dayanan veriler kullanılmıştır.

\subsubsection{Verilerin toplanması}

Aktüel ziyaretçi anket formunu kullanarak, talep fonksiyonundaki seyahat maliyetiyle ilgili değişkenleri türetmek üzere, ziyaretçilerin mevcut gezilerinin temel özellikleri öğrenilmeye çalışılmıştır. Bu kapsamda; ikamet, alanı ziyaret sayıları, ayları ve günleri, ziyaret amaçları, mevcut gezinin süresi, ziyaretçi grup büyüklüğü ve niteliği, ulaşım aracı, araç başına kişi sayısı ve gezi masrafları sorgulanmıştır. Talep fonksiyonunun alan kalitesi ile ilgili değişkenlerinin verilerini elde etmek üzere alandaki etkinlikler, alanı tercih nedenleri, alanın içerdiği tesisler, donatılar ve idari yönlerden yeterliliğine yönelik sorular anket formunda yer almıştır. İkame rekreasyon alanlarına ait değişkenleri türetmek için ise, bu nitelikteki orman içi ve dışı rekreasyon alanlarına ziyaret sayıları sorulmuştur. Anket formunda son olarak, demografik ve sosyoekonomik niteliklere ilişkin değişkenler türetmek üzere; ziyaretçinin yaşı, eğitimi, geliri, hane halkı büyüklü- 
ğ̈̈ vb. kişisel özellikleri sorgulanmıştır.

Potansiyel ziyaretçi anket formu soruları, büyük ölçüde aktüel ziyaretçi anket formuna benzemektedir. Aralarındaki en belirgin fark, aktüel ziyaretçi anketlerindeki mevcut gezi kesiti yerine, potansiyel ziyaretçi anket formunda son bir yıl içinde Ankara ilinde orman içi rekreasyon alanlarına gerçekleştirilen son geziye ilişkin bilgilerin sorgulanmasıdır.

Araştırmada anket çalışması için aktüel ve potansiyel ziyaretçilerin örnek büyüklükleri hesabında Formül 6'da verilen ana kütle büyüklüğü bilinen olasılıklı örnekleme formülü (Yazıcıoğlu ve Erdoğan, 2004; Daşdemir, 2016) kullanılmıştır:

$$
n \geq N . p . q . Z^{2} /\left[(N-1) \cdot d^{2}+p \cdot q \cdot Z^{2}\right]
$$

Formül 6'da n, örnek büyüklüğünü; N, ana kütle büyüklüğünü; $p$, ölçülmek istenen özelliğin ana kütle içerisinde bulunma olasılığını; q, ölçülmek istenen özelliğin ana kütle içerisinde bulunmama olasılığını; Z, \%95 güven düzeyinde $\mathrm{Z}$ test değerini $(1,96)$; d, hata payını göstermektedir.

Aktüel ziyaretçiler için ana kütle büyüklüğü $\left(\mathrm{N}_{1}\right)$, çalışma alanındaki orman içi rekreasyon alanlarına yıllık ziyaret sayısıdır ve yaklaşık 301.000 kişi olarak belirlenmiştir (OGM, 2014b; OSB IX. Bölge Müdürlüğü, 2014). Potansiyel ziyaretçiler için ana kütle büyüklüğü $\left(\mathrm{N}_{2}\right)$ ise Ankara ili hane halkı say1s1 olan 1.572.133'dür.

Bölgesel seyahat maliyeti yaklaşımının geçerliliği için, ikame ilişkilerini dikkate alarak istenen özellik (p), "deneklerin son bir y1l içinde birden fazla alanı ziyaret etmesi” olarak öngörülmüştür. İlk 100'er anket çalışması sonuçlarına göre, deneklerin birden fazla alanı ziyaret etme olasılığı \%25 (p), etmeme olasılığ 1 ise \%75 (q) olarak kabul edilmiştir. Potansiyel ziyaretçi anketlerinde örnek büyüklüğünü artırmak için p, \%50 olarak alınmıştır.

Hata payı (d), potansiyel ziyaretçiler için 0,05 olarak kabul edilirken, aktüel ziyaretçiler için daha homojen grup olmalarını ve araştırma maliyetlerini dikkate alarak, biraz daha yüksek $(0,07)$ alınmıştır. $\mathrm{Bu}$ değerler Formül 6'da yerleştirildiğinde örnek büyüklüğünün aktüel ziyaretçiler $\left(\mathrm{n}_{1}\right)$ için en az 147 ziyaretçi, potansiyel ziyaretçiler $\left(\mathrm{n}_{2}\right)$ için en az 384 hane halkından oluşması gerektiğ

Minimum örnek büyüklükleri aktüel ziyaretçiler için alan bazında yıllık ziyaretçi sayısı, potansiyel ziyaretçiler için ilçeler bazında hane halkı sayısına göre tabakalandırılmıştır. Bazı tabakalardaki düşük örnek sayılarını artırmak üzere, aktüel ziyaretçiler için minimum örnek büyüklüğü 20 olarak kabul edilmiş, potansiyel ziyaretçiler için 5'in katları olacak şekilde yukarıya doğru yuvarlama yapılmıştır.

Anket çalışmaları, Temmuz 2014 - Ağustos 2016 arasında yapılmıştır. Aktüel ziyaretçi anketleri araştırma alanı içinde kalan orman içi rekreasyon alanlarında ve ziyaretçi grubu temsilcileriyle gerçekleştirilmiştir. Potansiyel ziyaretçi anketleri için ise ilçe merkezlerinde ve hane halkı temsilcileriyle, basit rasgele örnekleme yöntemiyle çalışılmıştır. Toplamda 350 aktüel ziyaretçi, 600 potansiyel ziyaretçi anketi gerçekleştirilmiş, hatalı ve eksik doldurulan anketler elenerek 312 aktüel, 556 potansiyel ziyaretçi anketi değerlendirilmiştir.

Rekreasyon alanlarının niteliklerine dayanan objektif değişkenler türetmek için Gülez (1990) tarafından geliştirilen rekreasyon potansiyeli değerlendirme ölçeği kullanılmıştır. Ziyaret orijinleri ve orman içi rekreasyon alanları arasındaki uzaklık ve ulaşım süresi, "Google Haritalar” web aracıyla ölçülerek elde edilmiştir. Rekreasyon potansiyeli için gerekli iklim verileri (yaz ayları sıcaklık, yağış, bulutlu gün sayısı ve rüzgâr h1z1), uzun yıllar ortalaması olarak yakın istasyonlar için Meteoroloji Genel Müdürlüğünden temin edilmiştir. Yerleşim yerlerinin demografik ve sosyoekonomik nitelikleri ile deneklerin gelir ve harcamalarının analiz zamanındaki değerinin hesabında kullanılan tüketici fiyatları endeksi $(2003=100)$ Türkiye İstatistik Kurumu web sayfasından (TÜİK, 2016) temin edilmiştir.

\subsection{4. İstatistik analizler ve talep eğrilerinin türetilmesi}

Talep fonksiyonu türetmek için aktüel ve potansiyel ziyaretçi anketlerinden elde edilen son gezi verileri, alanlar bazında birleştirilerek rekreasyon alanı -ziyaret orijini (ilçe) kombinasyonları oluşturulmuştur. Anket formlarından elde edilen verilerin işlenmesi, nitel verilerin sayısallaştırılması, değişkenlerin türetilmesi, aritmetik ortalamalar, yüzde hesapları gibi basit istatistik analizler ve grafiklerin hazırlanmasında MS Office Excel yazılımı kullanılmıştır. Çoklu korelasyon ve çoklu regresyon analizleri ise SPSS 24.0 yazılımı ile gerçekleştirilmiştir.

Talep fonksiyonu için değişkenler seçerken, otokorelasyon probleminden sakınmak üzere çoklu korelasyon analizinden faydalanılmış, çoklu regresyon analizinde ise birçok fonksiyon tipi denenerek yarı logaritmik (Formül 7) fonksiyon tipinin kullanılmasına karar verilmiştir:

$$
\begin{aligned}
\ln \left(K A T O R_{i j}\right)= & \alpha_{0}+\beta S M_{i j}+\gamma G_{i}+\delta A K_{i j}+\partial i K_{i j}+ \\
& \theta D S E_{i}+\vartheta Z T_{i}+\varepsilon
\end{aligned}
$$


Talep fonksiyonları türetildiğinde, talebi etkileyen değişkenlerle ilgili analizler bu fonksiyonlar üzerinde yapılırken, kuramsal olarak artırılan seyahat maliyetleriyle ikinci aşama talep eğrisi çizilmiştir. Giriş ücretleri artışı-gelir değişimi ve talep esneklikleri hesapları ikinci aşama talep eğrileri üzerinde yapılmıştır. İkinci aşama talep eğrisi üzerinde A noktasından $\mathrm{B}$ noktasına hareket edildiğinde ziyaret sayıs1 $\mathrm{ZS}_{\mathrm{A}}$ 'dan $\mathrm{ZS}_{\mathrm{B}}$ 'ye, seyahat maliyeti de $\mathrm{SM}_{\mathrm{A}}$ 'dan $\mathrm{SM}_{\mathrm{B}}$ 'ye değiştiğinde, $\mathrm{AB}$ arasında talebin yay esnekliği Formül 8 yardımıyla hesaplanmıştır.

$$
E_{A B}=\frac{Z S_{B}-Z S_{A}}{Z S_{B}+Z S_{A}} \times \frac{S M_{B}-S M_{A}}{S M_{B}+S M_{A}}
$$

Rekreasyon talep fonksiyonları üzerinde seyahat maliyetlerindeki değişimin yanı sıra, diğer değiş- kenler kullanılarak da iktisadi-sosyal analizler yapılabilmektedir. Bu doğrultuda öne çıkan bağımsız değişkenler üzerinde kuramsal artış ve azalışlar öngörülerek, geleceğe yönelik olarak toplam rekreasyon talebindeki değişimler tahmin edilmiştir.

\section{Bulgular}

\subsection{Ziyaretçiler ve davranışları üzerine genel bulgular}

Aktüel ve potansiyel ziyaretçi anket çalışması gerçekleştirilen deneklerin ortalama 40 yaş ve üstü, \%82'den fazlasının erkek, hane halkı büyüklüğünün 3,6'dan fazla, eğitimlerinin liseden yüksek olduğu belirlenmiştir. Aktüel ve potansiyel ziyaretçi anket verilerine göre, deneklerin rekreasyonel davranışlarına ait temel bulgular Tablo 2'de verilmiştir.

Tablo 2. Deneklerin Temel Rekreasyonel Özellikleri

Table 2. Basic recreational characteristics of the respondents

\begin{tabular}{lcc}
\hline Nitelik & Aktüel ziyaretçiler & Potansiyel ziyaretçiler \\
\hline İlk kez ziyaret oranı (\%) & 39,4 & $\mathrm{n} / \mathrm{a}$ \\
Ortalama yıllık ziyaret sayısı & 3,49 & 3,44 \\
Çok amaçlı gezilerin oranı (\%) & 31,1 & 22,6 \\
Ortalama gezi süresi (saat) & 9,70 & 7,69 \\
Alanda ortalama rekreasyon süresi (saat) & 8,08 & 6,05 \\
Ulaşım aracı-otomobil (\%) & 88,5 & 88,9 \\
Ulaşım aracı-kişisel (\%) & 91,7 & 88,9 \\
Kişisel araçta kişi sayıs1 & 3,79 & 3,76 \\
Ortalama ziyaretçi grubu büyüklüğüu & 5,41 & 5,46 \\
$<18$ ziyaretçi sayısı & 1,40 & 1,19 \\
nna: Veri yok & &
\end{tabular}

Aktüel ziyaretçilerin yaklaşık \%40'1 orman içi rekreasyon alanlarını ilk kez ziyaret etmiştir. Son bir yıl içinde ziyaretçilerin alanları 3 defadan fazla ziyaret ettikleri, son gezileri dikkate alındığında uzun zaman geçirdikleri, ortalama ulaşım süresinin 1,5 saatten fazla olduğu, ulaşımda kişisel araçlarını, özellikle otomobilleri kullandıkları görülmüştür. Ziyaretçi grupları 5 kişiden büyüktür ve her grupta 18 yaşından küçük en az bir ziyaretçi bulunmaktadır. Rekreasyon etkinlikleri incelendiğinde aktüel ve potansiyel ziyaretçilerin \%83'ünün piknik etkinliği, en az \%70'inin mangal, \%60'inın manzara seyretmek, \%50'sinin yürüyüş yapmak, \%35'inin doğa gözlemi etkinliklerini gerçekleştirdiği belirlenmiştir.

\subsection{Talebi etkileyen değişkenler ve birinci aşama bölgesel orman içi rekreasyon talep fonksiyonları}

Talep fonksiyonlarında yer alan değişkenlerin tanımları, betimleyici istatistikleri (aritmetik ortalama, ; standart sapma, $\sigma)$ ve beklenen işaretleri $(+/-)$
Tablo 3'de gösterilmiştir. Seyahat maliyeti, ikame etkinliklerin kalitesi ve çeşitliliği dışındaki değişkenlerin işaretlerinin pozitif olması beklenmiştir.

Aktüel ve potansiyel ziyaretçi verileri kullanılarak çoklu regresyon analizleriyle kurulan iki bölgesel talep fonksiyonu, Tablo 4'te verilmiştir. Her iki fonksiyon da \%99 güven düzeyinde anlaml1dir. Birinci talep fonksiyonu, rekreasyon alanlar1na ziyaretlere orijin zonlarından katılım oranının $\% 59$, 1'ini, ikinci fonksiyon ise \%54,1'ini açıklamaktadır. Birinci aşama niteliğindeki talep fonksiyonlarının her birinde seyahat maliyeti değişkeni \%99 güven düzeyinde anlamlıdır ve işaretleri beklendiği gibi negatiftir.

SMY'nin doğasına uygun olarak, seyahat maliyetleri arttıkça katılım oranının azaldığı ortaya çıkmaktadır. Ziyaret edilen alanın kalitesini gösteren dört değişkenden, STATÜ ve REKPOT değişkenleri de $\% 99$ güven düzeyinde anlamlıdır ve işareti beklendiği gibi pozitiftir. Mesire yerlerinden milli parka doğru korunan alan statüsü değiştikçe, ala- 
Tablo 3. Talep fonksiyonlarında yer alan değişkenlerin tanımları, betimleyici istatistikleri ve beklenen işaretleri Table 3. Definitions, descriptive statistics and expected signs of variables in demand equations

\begin{tabular}{|c|c|c|c|c|}
\hline Değişkenler & Tanımlar & $\overline{\mathrm{x}}$ & $\sigma$ & $+/-$ \\
\hline KATOR & i. orijin zonundan (ilçeden) j. rekreasyon alanına ziyaretlere katılım oranı & 0,074 & 0,504 & * \\
\hline SEMAL & $\begin{array}{l}\text { i. zondan j. rekreasyon alanına son ziyarette deneklerin ortalama seyahat maliyeti } \\
\text { (ulaşım harcamaları, giriş ücreti ve ulaşım zamanının fırsat maliyeti toplamı) }\end{array}$ & 495,93 & 538,91 & - \\
\hline ETKÇEŞ & $\begin{array}{l}\text { j. alanda piknik dışındaki etkinlik fırsatları çeşitliliğinin yeterliliğine yönelik ziya- } \\
\text { retçilerin inançlarının ortalama puanı }\end{array}$ & 3,08 & 0,78 & + \\
\hline STATÜ & j. alanın statüsü: milli park (3), tabiat park1 (2), mesire yeri veya kent ormanı (1) & 1,81 & 0,79 & + \\
\hline REKPOT & j. rekreasyon alanının Gülez (1990)'daki araçla rekreasyon potansiyeli & 65,94 & 8,95 & + \\
\hline İKETKÇEŞ & $\begin{array}{l}\text { j. alan için i. orijine en yakın alanda etkinlik fırsatlarının yeterliliğine yönelik ziya- } \\
\text { retçilerin inançlarının ortalama puanı }\end{array}$ & 3,23 & 0,46 & - \\
\hline İKETKLT & $\begin{array}{l}\text { j. alan için i. orijine en yakın alanda etkinliklerin kalitesine yönelik ziyaretçilerin } \\
\text { inançlarının ortalama puanı }\end{array}$ & 3,30 & 0,42 & - \\
\hline İKUZ & j. alan için i. orijine en yakın alanın uzaklığ $1(\mathrm{~km})$ & 21,02 & 19,08 & + \\
\hline KGELİR & i. orijinden ziyaretçilerin aylık kişisel gelirlerinin ortalaması & $3.014,87$ & $1.321,53$ & + \\
\hline EĞİTİM & $\begin{array}{l}\text { i. zondan j. rekreasyon alanını ziyaret edenlerin eğitim seviyesi: İlkokul, 1; } \\
\text { ilköğretim, 2; Lise, 3; ön lisans, 4; lisans, 5; yüksek lisans, 6; doktora, } 7 \text {. }\end{array}$ & 3,44 & 1,22 & + \\
\hline ALISK & j. alanı alışkanlıkla ziyaret edenlerin oranı & 0,23 & 0,35 & + \\
\hline TESYET & j. alanı tesis ve donatıların yeterliliği için ziyaret edenlerin oranı & 0,09 & 0,21 & + \\
\hline YORESL & j. alanı yöresel yemekler için ziyaret edenlerin oranı & 0,09 & 0,25 & + \\
\hline
\end{tabular}

na yönelik rekreasyon talebi artmaktadır. Alanın rekreasyon potansiyeli yükseldikçe de ziyaret orijinlerinden rekreasyon gezilerine katılım oran1, dolayısıyla ziyaret sayısı artmaktadır. İki talep fonksiyonuna da anlamlı olarak giren kalite değişkeninin (ETKÇEŞ) işareti beklentinin aksine ne- gatif çıkmaktadır. Fonksiyonlarda orman içi rekreasyon alanlarının sunulan etkinlik firsatlarının çeşitliliği açısından yeterliliğine yönelik ziyaretçi inançları (ETKÇEŞ) arttıkça, ziyaretlere katılım oranının azaldığı görülmektedir.

Tablo 4. Birinci aşama bölgesel talep fonksiyonları Table 4. First stage regional demand functions

\begin{tabular}{|c|c|c|c|c|}
\hline \multirow[t]{2}{*}{ Değişkenler } & \multicolumn{2}{|c|}{ I. FONKSIYYON } & \multicolumn{2}{|c|}{ II. FONKSİYON } \\
\hline & Katsayı & $t$ değeri & Katsayı & t değeri \\
\hline Sabit & $-0,8756$ & $-0,553$ & $-4,5021 * *$ & $-2,484$ \\
\hline SEMAL & $-0,0021 * * *$ & $-5,886$ & $-0,0016 * * *$ & $-5,080$ \\
\hline ETKÇEŞ & $-0,5410 * *$ & $-2,574$ & $-0,4655 * *$ & $-2,208$ \\
\hline STATÜ & $1,2321 * * *$ & 5,143 & & \\
\hline REKPOT & & & $0,0757 * * *$ & 3,657 \\
\hline İKETKÇEŞ & $-0,9719 *$ & $-1,983$ & $-1,5029 * * *$ & $-4,253$ \\
\hline İKETKLT & $-0,7023$ & $-1,291$ & & \\
\hline İKUZ & $0,0257 * * *$ & 2,813 & $0,0320 * * *$ & 3,664 \\
\hline EĞİTİM & $-0,0434$ & $-0,316$ & & \\
\hline KGELİR & 0,0001 & 0,789 & & \\
\hline ALISK & $0,8672 *$ & 1,836 & $1,4037 * * *$ & 2,943 \\
\hline TESYET & $1,7774 * *$ & 2,337 & $1,2982 *$ & 1,733 \\
\hline YORESL & $-1,9672 * * *$ & $-2,831$ & $-2,9376 * * *$ & $-4,349$ \\
\hline Bağımlı Değişken & \multicolumn{4}{|c|}{ LN (KATOR) } \\
\hline Gözlem sayıs1 & \multicolumn{2}{|c|}{96} & \multicolumn{2}{|c|}{96} \\
\hline F-test & \multicolumn{2}{|c|}{$13,486 * * *$} & \multicolumn{2}{|c|}{$14,995^{* * *}$} \\
\hline $\mathrm{R}^{2}$ & \multicolumn{2}{|c|}{0,638} & \multicolumn{2}{|c|}{0,580} \\
\hline Düzeltilmiş $\mathrm{R}^{2}$ & \multicolumn{2}{|c|}{0,591} & \multicolumn{2}{|c|}{0,541} \\
\hline
\end{tabular}


Fonksiyonlarda ikame alanlarla ilgili üç değişken de (İKETKÇEŞ, İKETKLT ve İKUZ) anlamlı olarak yer almıştır ve işaretleri beklentilere uygundur. Ziyaretçilerin ikame alanda etkinlik fırsatlarının çeşitliliği ve kalitesinin yeterliliğine yönelik inançları (İKETKÇEŞ ve İKETKLT) arttıkça, ikame ettiği orman içi rekreasyon alanına ziyaretlere katılım oranı azalmaktadır. Katılım oranı, ikame alanın uzaklığıyla (İKUZ) ise ters orantılıdır. Ziyaretçilerin tercih ve beklentilerini açıklamak için alan tercih nedenlerini yansıtan ve üçüncü ve dördüncü talep fonksiyonunda anlamlı olarak yer alan üç değişkenden, alışkanlıklar (ALISK) ve tesislerin yeterliliğinin (TESYET) pozitif etkili olduğu görülmektedir. Yöresel yemekleri (YORESL) nedeniyle tercih edilmeyen alanlarda, ziyaretlere katılım oran1, beklentinin aksine daha yüksektir.
Ziyaretçilerin sosyoekonomik özelliklerini yansıtan değişkenlerden KGELİR ve EĞİTIM değişkenleri birinci fonksiyonda yer almıştır; ancak anlamlı değildir. KGELİR değişkeninin işareti, kişisel gelirin ziyaret oranlarını arttırıcı etkisini gösterirken, EĞİTIM değişkeninin işareti beklentilerin aksine negatiftir.

\subsection{Kuramsal değişimlerle bölgesel rekreasyon talep fonksiyonu bulguları}

\subsection{1. İkinci aşama talep eğrisi}

Literatür açıklanırken de belirtildiği gibi, bu tip araştırmalarda çoklukla ihmal edilmiş ikinci aşama talep eğrisi birinci talep fonksiyonundan türetilerek Şekil 2'de sunulmuştur.

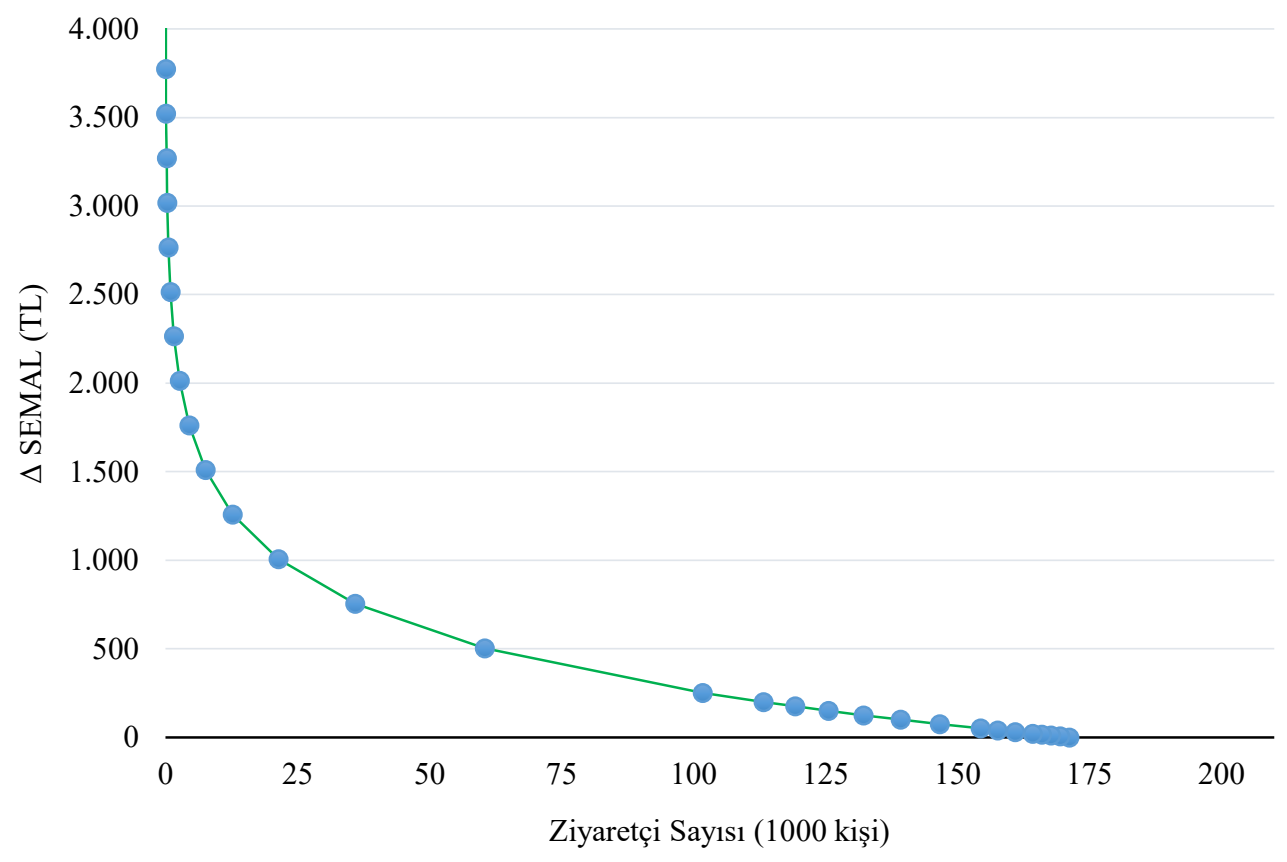

Şekil 2. Aktüel ve potansiyel ziyaretçiler için ikinci aşama talep eğrisi Figure 2. Second stage demand curve for actual and potential visitors

Şekil 3'teki talep eğrisinde de giriș ücretlerinin artması, kullanım bedellerinin istenmesi gibi yönetsel nedenlerle ortaya çıkabilen kuramsal seyahat maliyeti (SEMAL) artışları karşısında, ziyaret sayıları azalmaktadır. Bu ikinci aşama talep eğrisi yardımıyla, giriş ücretleri artışı karşısında Ankara ili orman içi rekreasyon alanlarının ziyaretçi say1ları ile gelir değişimleri ( $\Delta$ Gelir) ve talep eğrisinin farklı noktalarındaki yay esneklikleri $\left(\mathrm{E}_{\mathrm{AB}}\right)$ tahmin edilerek, Tablo 5'te verilmiştir.

Tablo 5'te talep fonksiyonlarının yapısının bir sonucu olarak, "Gelir" sütunlarının bir maksimumu gözlenmektedir. Seyahat maliyetlerindeki 503
TL'lik artışın, ziyaret sayısını yaklaşık 1/3 oranında düşürse de alan yönetimini maksimum gelire eriştirdiği görülmektedir. Seyahat maliyetlerinin 0 TL'den 251,61 TL düzeyine yükselmesi ziyaretçi sayılarının azalmasına neden olurken, toplam geliri artırıcı bir etki yapmaktadır. Ancak, $\Delta$ Gelir ve toplam gelir düzeyinin maksimum olduğu nokta olan 503,22 TL seviyesini geçen maliyet artışları hem ziyaretçi sayısının hem elde edilecek gelirlerin azalmasina neden olmaktadir.

Tablo 5'in yay esneklikleri (EAB) sütunları, Formül 8 yardımıyla hesaplanmıştır. İkinci aşama talep eğrisinde gelirin maksimum olduğu noktadan 
Tablo 5. Seyahat maliyetleri, gelir değişimi ve talep esneklikleri

Table 5. Travel costs, changes in revenues and demand elasticities

\begin{tabular}{crrrr}
\hline Ziyaret Say1S1 & \multicolumn{1}{c}{$\Delta$ SEMAL } & Gelir (TL) & $\Delta$ Gelir (TL) & $\mathrm{E}_{\mathrm{AB}}$ \\
\hline 171.222 & 0,00 & 0,00 & 0,00 & \\
169.461 & 5,00 & $847.302,62$ & $847.302,62$ & 0,01 \\
167.718 & 10,00 & $1.677 .175,11$ & $829.872,49$ & 0,02 \\
164.285 & 20,00 & $3.285 .701,71$ & $795.815,31$ & 0,04 \\
160.923 & 30,00 & $4.827 .687,19$ & $1.541 .985,48$ & 0,05 \\
154.404 & 50,00 & $7.720 .178,29$ & $1.414 .996,86$ & 0,09 \\
146.625 & 75,00 & $10.996 .840,14$ & $3.276 .661,85$ & 0,13 \\
139.237 & 100,00 & $13.923 .742,11$ & $2.926 .901,98$ & 0,18 \\
101.767 & 251,61 & $25.605 .542,46$ & $2.959 .972,43$ & 0,47 \\
$\mathbf{6 0 . 4 4 9}$ & $\mathbf{5 0 3 , 2 2}$ & $\mathbf{3 0 . 4 1 9 . 0 5 0 , 1 7}$ & $\mathbf{4 . 8 1 3 . 5 0 7 , 7 0}$ & $\mathbf{0 , 7 6}$ \\
35.927 & 754,83 & $27.118 .792,51$ & $-3.300 .257,66$ & 1,27 \\
21.353 & $1.006,44$ & $21.490 .291,90$ & $-5.628 .500,60$ & 1,78 \\
1 & 4780,592 & $4.780,59$ & $-2.828,10$ & 9,39 \\
\hline
\end{tabular}

sonra yay esnekliği 1'den büyük değerlere dönüşmektedir. Bu durum genel iktisadi kurallara da uygun bir bulgu olup, yüksek seyahat maliyetlerine karşılık gelen bölgede esneklik birden büyük hesaplanmışken, seyahat maliyetinin düşük, ziyaretçi sayısının yüksek olduğu noktalarda esneklik birden küçük bulunmuştur. Bununla birlikte seyahat maliyetlerinde, dolayısıyla giriş ücretinde kişi başına 5 TL'lik bir artış, esneklik 0'a yakın olduğundan, ziyaretçi sayısında önemli bir değişiklik yaratmadan Ankara ilinde orman içi rekreasyon alanlarından elde edilecek geliri yaklaşık 850.000 TL artırmaktadır.

\subsubsection{Talebi etkileyen diğer değişkenler}

Tablo 3'te açık tanımları verilen KGELIR, TESYET, İKETKÇEŞ, İKRTKLT ve İKUZ değişkenlerinin değerlerinde meydana gelebilecek kuramsal değişimler karşısında, bölgesel rekreasyon talebindeki olası değișiklikleri öğrenmek için, birinci talep fonksiyonu kullanılmıştır. REKPOT değişkeni ile yapılan iktisadi analizler ise ikinci talep fonksiyonu ile gerçekleştirilmiştir. Orman kaynakları yönetimi için dışsal bir değişken olan, kişi başına gelirin gelecekte, örneğin beş yıl sonra artacağı varsayıldığında farklı seviyelerdeki kuramsal artışlar karşısında, bölgesel rekreasyon talebindeki (ziyaret sayısı) tahmini değişim Şekil 3'te verilmiştir.

Şekil 3'e göre, mevcut orman içi rekreasyon alanlarının sayı, büyüklük ve kalitelerinde değişim olmadığı, ayrıca diğer değişkenlerin sabit olduğu varsayımıyla, kişi başına gelirin reel olarak 1.000 TL artmasi halinde, Ankara ilinde mevcut orman içi rekreasyon alanlarına yaklaşık 20.000 ziyaretçilik bir talep artışı gerçekleşmesi ön görülmelidir.
Gelir artışı 2.000 TL'ye yükseldiğinde ise, toplam ziyaretçi sayısında yaklaşık 43.500 ziyaretçilik bir artış olması beklenmelidir.

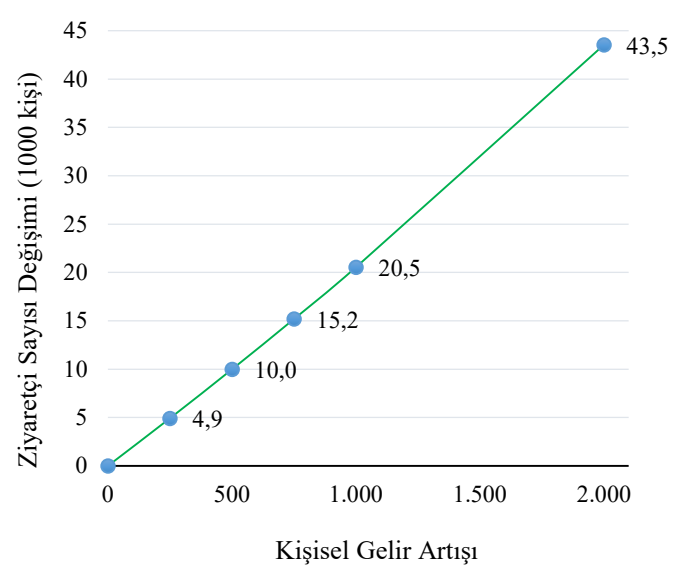

Şekil 3. Kişisel gelir-ziyaretçi sayısı etkileşimi Figure 3. Effects of individual incomes on recreation demand

Zamanla orman içi rekreasyon alanlarında tesis ve donatıların nicelik ve niteliğinin iyileştirilmesi, etkinlik olanaklarının artırılması, alan büyüklügünün genişlemesi, olumsuz etkenlerin azalması halinde araştırma alanlarının rekreasyon potansiyelleri (REKPOT) yükselecektir. Bölgesel düzeyde rekreasyon alanlarında oluşabilecek sayısal ziyaretçi artışlarını gösteren Şekil 4'e göre, her bir alanın rekreasyon potansiyelinin $\% 1$ artması halinde dahi, toplam rekreasyon talebi 12.650 ziyaretçi artmaktadır. Örneğin, gölet, kır gazinosu ve konaklama tesisleri inşası ile her alanın rekreasyon potansiyeli \%10 artırıldığında toplam ziyaretçi talebinin 182.000 kişi artacağı anlaşılmaktadır. 


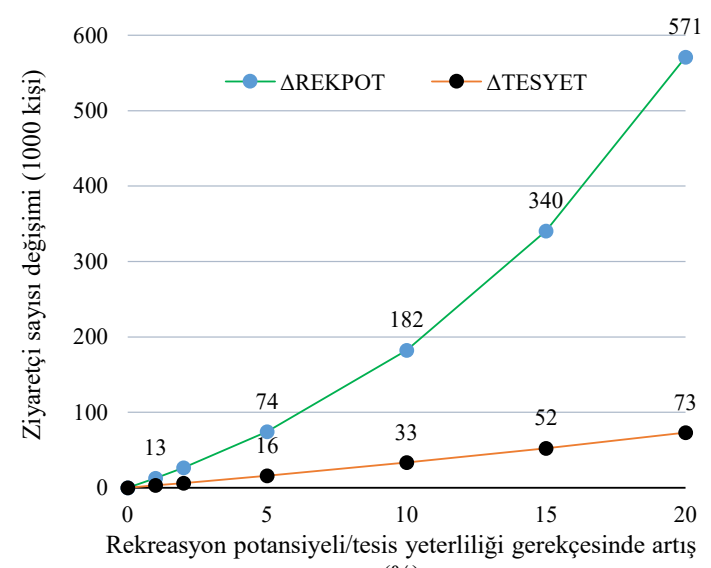

(\%)

Şekil 4. Alan kalitesinde iyileşmelerin ziyaretçi sayılarına olası yansımaları

Figure 4. Effects of site quality on recreation demand

Şekil 4'teki rekreasyon potansiyeli-talep analizi tekil alanlar için de kullanılabilmektedir. Örneğin, sadece Beynam Mesire yerinin rekreasyon potan- siyeli \%10 arttığında rekreasyon talebinin, mevcut ziyaretçi sayısından fazla, 9.200 kişi artacağı hesaplanabilmektedir.

Orman içi rekreasyon alanlarındaki tesis ve donatılar nitel ve nicel olarak iyileştikçe, ziyaretçilerin bu alanları tercihi artabilir. Şekil 4'e göre, örneğin beş yıllık bir yatırım projesi çerçevesinde Ankara ili orman içi rekreasyon alanlarında tesis ve donatılar1 toplumun beklentilerine uygun olarak $\% 5$, $\% 10$ ve $\% 20$ oranlarında iyileştirilirse (TESYET), bölgesel talep sırasıyla, yaklaşık 16.000, 33.500 ve 73.000 ziyaretçi kadar artmaktadır.

Bölgesel talep fonksiyonu, ikame alanlarda etkinlik fırsatları ve kalitesinin yeterliliği arttıkça, gözlem alanındaki ziyaretlere katılım oranının, dolayısıyla ziyaret sayısının azaldı̆̆ını göstermektedir. Şekil 5 ikame alanlarda etkinlik firsatlarının (IKETKFIR) ve etkinlik kalitesinin yeterliliğine (IKETKLT) yönelik ziyaretçilerin inanç seviyesindeki yüzdelik artışlar karşısında talep seviyesindeki düşüşleri göstermektedir.

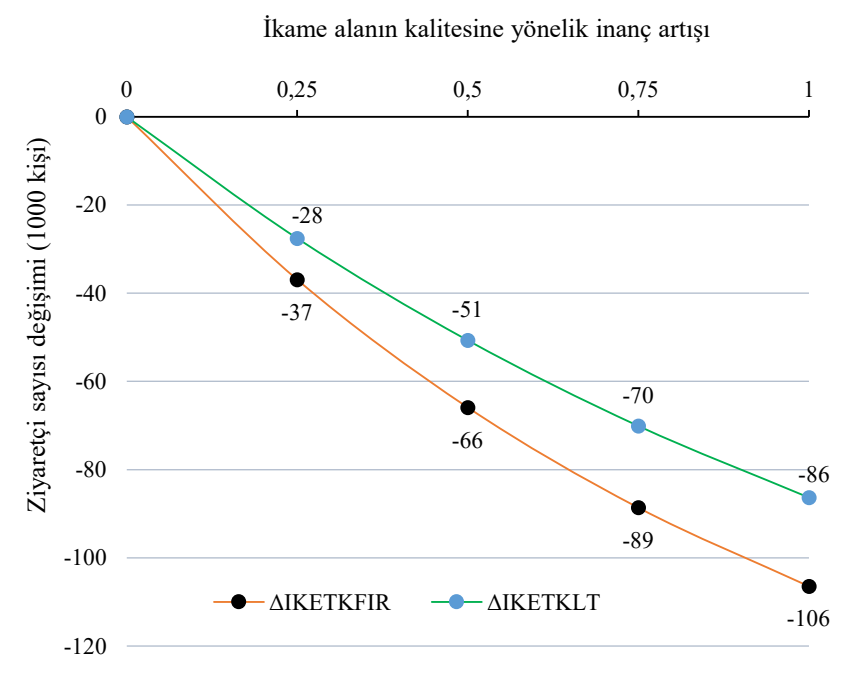

Şekil 5. İkame alanların kalitesi-ziyaretçi sayısı etkileşimi

Figure 5. Effects of quality of substitute sites on recreation demand

Şekil 6 ziyaretçilerin, ikame alanlarda etkinlik firsatlarının mevcut duruma göre bir seviye daha iyi olduğuna inanmaları halinde, orman içi rekreasyon alanlarında ziyaret sayısının yaklaşık 100.000 kişi azalacağını göstermektedir. Buna ek olarak, ikame alanlardaki rekreasyon etkinliklerinin kalitesine yönelik ziyaretçi inancının bir seviyelik artışının, orman içi rekreasyonel alanların bölgesel talebinde yaklaşık 86.000 ziyaretçi kadar azalışa neden olacağ1, Şekil 5'ten tahmin edilmektedir.

Ankara ilinde orman içi rekreasyon alanlarına yö- nelik bölgesel rekreasyon talebi fonksiyonundan türetilebilecek bir başka bulgu, ikame alanların uzaklığı ile rekreasyon talebi arasındaki etkileşimdir (Şekil 6).

Şekil 6'da x ekseni, ikame alanların uzaklığındaki değişimi ifade etmektedir. Eksendeki pozitif değerler, ikame alanların uzaklığındaki artışları, negatif değerler ise azalmayı göstermektedir. Buna karşın y ekseni, ziyaretçi sayısındaki değişimi açıklamaktadır. Bu eksendeki pozitif değerler, ziyaretçi sayısındaki artışları, eksi değerler ise azalmayı göster- 


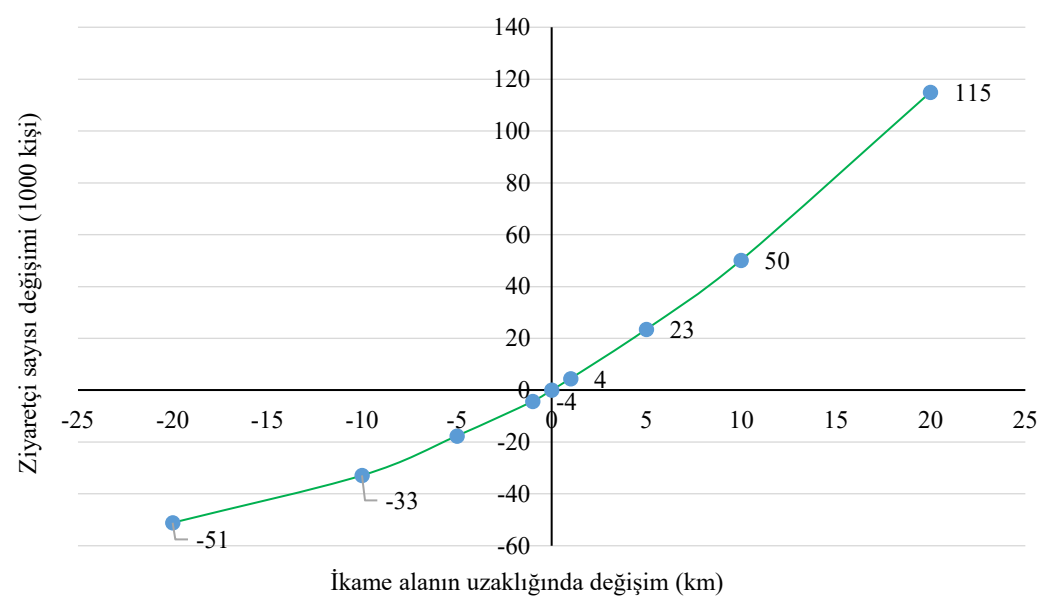

Şekil 6. İkame alan uzaklığ rekreasyon talebi etkileşimi

Figure 6. Effects of distance from substitute sites on recreation demand

mektedir. Şekil 6’ya göre, bir orman içi rekreasyon alanının çevresindeki ikame alanların uzaklığında 10 km'lik bir artış, mevcut rekreasyon talebini 50.000 ziyaretçi artırmaktadır. 10 km'lik azalma ise talebi yaklaşık 33.000 ziyaretçi kısmaktadır.

\section{Tartışma ve Sonuç}

Ulusal literatürde araştırma sonuçlarının karşılaştır1labileceği ve değerlendirileceği bir bölgesel rekreasyon talebi araştırması bulunmamaktadır. Bununla birlikte, araştırma alanlarının toplam ziyaretçi sayısının büyük bölümünü oluşturan Soğuksu Milli Parkı için yıllar önce gerçekleştirilen tek alan11-zonal SMY araştırmasının (Kaya ve ark., 2000) ötesinde bu araştırmada; alan kalitesi, ikame alanların kalitesi ve ziyaretçilerin sosyoekonomik özellikleriyle ilgili bazı değişkenler de kullanılmıştır.

Araștırmada üretilen talep fonksiyonlarındaki en şaşırtıcı bulgu, ziyaretçilerin piknik dışındaki etkinlikler ve etkinlik çeşitliliği açısından daha yetersiz buldukları alanları daha çok ziyaret etmeleridir. Oysa alanın kalitesi ile ziyaret sayısının doğru orantılı olması gerekir. Ziyaretçilerin büyük bölümünün piknik ve mangal etkinliklerini gerçekleştirmesi, alanların diğer etkinlikler için kullanılmasına kayıtsız kalmalarını açıklayabilir. Ancak piknik dışındaki etkinliklerin ve çeşitliliğinin yeterli olmasına yönelik inançları ile ziyaret oranları arasındaki negatif ilişki, piknik-mangal bileşkesi dişındaki etkinlikleri alanda görmek istemediklerini ima etmektedir. İlde nüfus yoğunluğunun yüksek olduğu ilçelerdeki belediye piknik alanlarında gözlenen taşıma kapasitesinin oldukça üzerindeki kullanımlar da bu iddiayı doğrulayabilir. Bu noktada yapılması gereken, toplumun belediye piknik alanlarındaki alışkanlıklarını ve rekreasyon davranışlarını doğal ekosistemler olan ormanlara taşımasının önünü açmak ve orman içi rekreasyon alanlarını benzer tesisler haline getirmek olmamalıdır. Toplumun rekreasyon davranışlarını dönüştürücü ve alternatif rekreasyon etkinlikleri için talep yaratıcı çalışmalar yapılmalıdır.

Eğitim seviyesi ile orman içi rekreasyon alanlarına ziyaret sayısı arasındaki negatif ilişkinin şimdilik geçerli olduğu ve son yıllardaki yüksek göç ve kentleşme oranlarının etkisiyle kırsala duyulan özlemin artışından kaynaklandığı düşünülmektedir. Geleceğe yönelik senaryolar düşünülürken, eğitimin azalacağı bir durum için tasarım yapmak yerine, gelecekte eğitim seviyesi daha yüksek bir toplumun beklentilerine uygun rekreasyon firsatları sağlamak üzere hazırlık yapılmalıdır.

Bir başka ilginç bulgu, yöresel yemekler nedeniyle tercih edilen alanlarda ziyaret sayısının azalmasıdır. Restoran işletmeciliğinin ön plana çıktığı sahalardan kaynaklandığı düşünülen böyle durumlarda sürdürülebilir faydalanma için restoranlar orman içi rekreasyon etkinlikleri ile uygun şekilde bütünleştirilmelidir.

Aktüel ve potansiyel ziyaretçilerin son gezileri hakkında toplanan verilerin bütünleştirilmesiyle oluşturulan birinci talep fonksiyonu ve elastikiyet değerleri dikkate alındığında aşağıdaki sonuçlar ortaya çıkmaktadır:

- Aktüel ve potansiyel ziyaretçi anketi verilerinin kapsadığı araştırma alanı içerisinde kalan rekreasyon alanlarının ziyaretçi talebi dikkate alındığına, 0-503 TL aralığında seyahat maliyetlerinin artması araştırma alanlarından elde edilebilecek gelir düzeyini artırmaktadır. $\mathrm{Bu}$ aralıkta hesaplanan elastikiyet değeri 0,01 ile 0,76 arasında değişmektedir. Bir başka deyişle, 
talep fonksiyonunun inelastik olduğu bir durum gözlenmekte ve alan yöneticisinin seyahat maliyetlerini artıracak, giriş ücreti, otopark ücreti, etkinlik bedeli, vb. kararlarının, elde edeceği gelirleri artırması beklenmelidir.

- Buna karşılık, hesaplanan esneklik değerinin 1'den büyük değerlere dönüştüğü, 755 TL ve üstü seyahat maliyeti artışları, gelirleri azaltan bir sonuç yaratmaktadır. Ziyaretçilerin rekreasyon maliyetlerini 755 TL ve daha büyük değerde artıran kararlar alan yöneticilerinin gelirlerini azaltıcı etki yapmaktadır. Bu nedenle alınan kararların sadece ziyaretçi sayılarına etkisine odaklanmak yerine, gelir etkisinin de dikkate alınması, bunun için de talep ve elastikiyet özellikleriyle ilgilenilmesi gereklidir.

- Toplam ziyaretlerin büyük bölümünü karşılayan Soğuksu Milli Parkı ve birçok alanda giriş veya otopark ücreti ve alanda alışveriş olanaklarının olmaması, birçok bulguya yansımıştır. İkinci aşama talep eğrisiyle yapılan analizler, ilde ziyaretçilerin uygulanan giriş ücretleri veya otopark ücretlerinin çok üzerinde tüketici rantı elde ettiğine işaret etmektedir. Taşıma kapasitesini aşan kullanımlar veya alanlardan sürdürülebilir faydalanma için tehdit oluşturan bir kalabalık oluştuğunda, giriş ücretleri veya belirli tesis veya ekipman kullanım bedelleri talep edilerek, faydalanma düzenlenebilir. $\mathrm{Bu}$ doğrultuda ikinci aşama talep eğrisi geniş bir olanak olduğunu kanıtlamaktadır. Ancak bu olanağın kullanımının sınırsız olduğu düşünülmemelidir. Kullanım bedelleri arttığında, talebin esnek olduğu noktaya kadar gelirlerde bir azalma öngörülmemesine rağmen, azalan ziyaretçi sayısının toplumun sağlık harcamalarında artış anlamına gelebileceği göz önünde tutulmalidir.

- Bölgesel talep fonksiyonları, tekil alanlar için talep değişimlerinin kestirilmesine de olanak sağlamaktadır.

Talep fonksiyonu kullanılarak yapılan geleceğe yönelik tahminler, talebi etkileyen değişkenlerin değerlerindeki küçük değişikliklerin bölgede mevcut ziyaretçi sayısının çok üzerinde bölgesel talep artışlarına yol açacağını göstermektedir. Araştırmanın kanıtladığı rekreasyonel ikame ilişkilerinden yola çıkarak, orman içi rekreasyonel arzı artırmaya karar vermeden önce, gelecekte kişi başına gelir ve belediyelerin piknik alanı kapasitelerindeki değişimler ciddi şekilde takip edilmelidir.
Yeni alanların tesisinde talep değişimlerine dikkat edilmelidir. İhtiyaç olduğunda dahi, yeni alan tesislerinin ikame ilişkilerine dahil olacağ 1 , türetilen talep fonksiyonlarından görülmektedir. Bölgesel düzeyde mevcut orman içi rekreasyon alanları sistemine yeni bir alanın eklenmesi veya eksiltilmesinin yaratacağı rekreasyon talebi değişiminin ikame alanlara yönelik talep üzerindeki etkileri talep fonksiyonları yardımıyla irdelenmelidir.

Araştırmada karşılaşılan ve rekreasyon kaynakları yönetimi açısından taleple ilgili en önemli sorun, "müşterilerim - muhataplarım kimlerdir" sorusuna verilen yanıtın belirsizliğidir. Bu belirsizlikle çağdaş pazarlama yaklaşımına ulaşmak mümkün değilken, Türkiye'de rekreasyon kaynakların kaç kullanıcısı olduğuna dair güvenli bir yanıt bulunmak güçtür. Türkiye'de birçok alanda olduğu gibi Ankara ilinde de orman içi rekreasyon alanlarının ziyaretçi sayıları belirsizdir. Birçok alanda girişler denetimsizdir. Giriş ücreti alınmamakta veya kayıtları düzenli tutulmamaktadır. Ziyaretçi istatistikleri ise tutarsızdır. Talep araştırmalarının sağlıklı yapılabilmesi için girişlerin denetimli olması, ziyaretçi istatistiklerinin düzenli tutulması gerekir.

Bu araştırma, Türkiye'de ilk defa rekreasyon alanlarına yönelik talebin tahmin edilmesine bölgesel-zonal bir yaklaşım getirmiş, orman kaynakları yönetiminde sayısal iktisadi analizlerin önemini vurgulama doğrultusunda katkı yapmaya çabalamıştır. Sürdürülebilir rekreasyonel hizmet yönetimini sağlayabilmek için bu tür araştırmaların düzenli olarak gerçekleştirilmesi gerekmektedir. Gelecekteki araştırmalarda daha ileri ekonometrik teknikler ve bölgesel (çok alanlı)-bireysel yaklaŞımlar kullanılarak ülkedeki metodolojik gelişim sağlanmalıdır.

Not: Bu makale, 2013-2016 yıllarında T.C. Orman ve Su İşleri Bakanlığı, Orman Genel Müdürlüğü, İç Anadolu Ormancılık Araştırma Enstitüsü Müdürlüğünce "Seyahat Maliyeti Yöntemi ile Ankara İlinde Orman İçi Rekreasyon Alanlarına Yönelik Bölgesel Talebin Tahmini” başlıklı projenin, OGM Araştırma İhtisas Grupları Toplantısında yayınlanması yönünde karar verilen Sonuç Raporunun özetidir.

\section{Kaynaklar}

Abdullah, N.M., 1988. Estimation of average and incremental net economic values of Oregon ocean sport caught salmon: An aggregated travel cost approach. $\mathrm{PhD}$ dissertation. Oregon State University.

Akesen, A., 1983. Fethiye Yöresinde Rekreasyon Amac1 ile Kullanılan Bazı Orman Alanlarında Rekreasyon Talep Değerinin Belirlenmesi Üzerine Araştırmalar, İstan- 
bul Üniversitesi Orman Fakültesi Yayınları, Yayın No: 346, İstanbul.

Başar, H., 2007. Dilek Yarımadas1-Büyük Menderes Deltas1 Milli Parkının Rekreasyon Amaciyla Kullan1mının Ekonomik Değerinin Saptanması: Bir Seyahat Maliyeti Uygulamas1, Ege Üniversitesi, Fen Bilimleri Enstitüsü, Tarım Ekonomisi Anabilim Dalı, Yüksek lisans Tezi, İzmir.

Bestard, A. B., Font, A. R., 2010. Estimating the aggregate value of forest recreation in a regional context. Journal of Forest Economics, Elsevier, vol. 16(3), pages 205-216, August.

Brinegar, H., Ward, F. A., 2009. Basin Impacts of Irrigation Water Conservation Policy, Ecological Economics, 69, 414-426.

Carson, R. T., Hanemann, W. M., Wegge, T. C., 2009. A nested logit model of recreational fishing demand in Alaska. Marine Resource Economics, 24(2), 101-129.

Cesario, F. J., Knetsch, J. L., 1970. The Time Bias in Recreation Benefit Estimates. Water Resources Research, 6, 700-704.

Clawson, M., 1959. Methods of Measuring the Demand for and Value of Outdoor Recreation. The Economics of The Environment, Wallace E. Oates, Edward Elgar Publishing, ISBN. 1-85898-002-X, Cheltenham.

ÇOB, 2004. Ulusal Ormancılık Programı (2004-2023), Çevre ve Orman Bakanlığı, Ankara.

Daşdemir, İ., 2016. Bilimsel Araştırma Yöntemleri. Nobel Akademik Yayıncılık ve Danışmanlık Tic. Ltd. Şti., Yayın No: 1536, 210 s., Ankara.

English, D. B. K., Betz, C., J., Young, J. M., Bergstrom, J. C., Cordell, H. K., 1993. Regional demand and supply projections for outdoor recreation. Gen. Tech. Rep. RM230. Fort Collins, CO: U.S. Department of Agriculture, Forest Service, Rocky Mountain Forest and Range Experiment Station, $39 \mathrm{p}$.

Garber-Yonts, B., 2005. Conceptualizing and Measuring Demand for Recreation on National Forests: A Review and Synthesis. Gen. Tech. Rep. PNW-GTR-645. Portland, OR. US Department of Agriculture, Forest Service, Pacific Northwest Research Station.

Geray, U., 1972. Ormanın Rekreatif Gayeyle Kullanılmasında Ekonominin Yeri. İ. Ü. Orman Fakültesi Dergisi, Seri A, Cilt 22, No.1.

Gülez, S., 1990. Orman içi Rekreasyon Alanının Saptanması İçin Geliştirilen Bir Değerlendirme Yöntemi, I.Ü. Orman Fakültesi Dergisi, A, 40/2: 132-147, İstanbul.

Gürlük, S. (2006) Manyas Gölü ve Kuş Cenneti'nin Çevresel Değerlemesi Üzerine Bir Araştırma. Uludağ Üniversitesi Fen Bilimleri Enstitüsü, Doktora Tezi, Bursa.

Heal, G. M., Barbier, E. B., Boyle, K. J., Covich, A., Gloss, S. P., Hershner, C. H., 2005. Valuing Ecosystem
Services: Towards Better Environmental Decision-making. Washington DC: National Academies Press.

Hill, G. W., Courtney, P. R., 2006. Demand analysis projections for recreational visits to countryside woodlands in Great Britain. Forestry, 79(2), 185-200.

Hof, J. G., Loomis, J. B., 1983. Recreation Optimization Model Based on the Travel Cost Method. Western Journal of Agricultural Economics, 8(1), pp. 76-85

Hotelling, H., 1947. Letter Cited on Page 9 in R. A. Prewitt, 1949. The Economics of Public Recreation: An Economic Study of Monetary Valuation of Recreation in The National Parks. U. S. Dep. of Interior, National Park Service, Washington, D. C.

İlter, E., Ok, K., 2012. Ormanc1l1k ve Orman Endüstrisinde Pazarlama İlkeleri ve Yönetimi. 3. Bask1, 423. s., İstanbul.

Kaya, G., Daşdemir, İ., Akça, Y., 2000. Soğuksu Milli Parkının Ekonomik Değerinin Belirlenmesi. Bartın Orman Fakültesi Dergisi, 1-2, 59-87.

Kaya, G., 2002. Pazarı Olmayan Ürünler Çerçevesinde Orman Ürünlerinin Değerinin Belirlenmesi, İstanbul Üniversitesi Fen Bilimleri Enstitüsü, Basılmamış Doktora Tezi, İstanbul.

Kaya, G., Aytekin, A., Yıldız, Y., Şaltu Z., 2009. Bartın İlinde Yaban Hayatı Kaynaklarını Korumanın ve Avlanma Hizmetinin Ekonomik Değerinin Belirlenmesi. TÜBİTAK 1070072 Projesi Sonuç Raporu.

Loomis, J. B., 1988. The bioeconomic effects of timber harvesting on recreational and commercial salmon and steelhead fishing: A case study of the Siuslaw National Forest. Marine Pollution Bulletin 5:43-60.

Loomis, J. B., Sorg, C. F., Donnely, D. M., 1986. Evaluating Regional Demand Models for Estimating Recreation Use and Economic Benefits: A Case Study, Water Resources Research, Vol. 22, No. 4, p. 431.

Lutz, J., Englin, J., Shonkwiler, J. S., 2000. On the Aggregate Value of Recreational Activities: A Nested Price Index Approach Using Poisson Demand Systems. Environmental and Resource Economics, 15(3), 217-226.

McKean, J. R., Johnson, D., Taylor, R. G., Johnson, R. L., 2001. The Value of Sport Fishing in the Snake River Basin of Central Idaho. Western Agricultural Economics Association, 2001 Annual Meeting, July 8-11, 2001, Logan, UT.

McKean, J. R., Johnson, D., Taylor, R. G., Johnson, R. L., 2005. Willingness to pay for non-angler recreation at the lower Snake River reservoirs. Journal of Leisure Research, 37(2), 178-194.

OGM, 2014a. Orman Genel Müdürlüğü 2014 Y11ı Faaliyet Raporu, Ankara.

OGM, 2014b. Orman Genel Müdürlüğü Mesire yerleri Bilgi Cetveli. Ankara orman Bölge Müdürlüğü Odun 
D1şı Ürün ve Hizmetler Şube Müdürlüğü, Ankara.

OGM, 2016. Ormancıllk İstatistikleri. http://www.ogm. gov.tr/ekutuphane/Sayfalar/Istatistikler.aspx (Ziyaret Tarihi: 01.10.2016).

OSB, 2016. Orman ve Su İşleri Bakanlığ1 web sayfası. http://www.ormansu.gov.tr/ (Ziyaret Tarihi: 01.10.2016).

OSB IX. Bölge Müdürlüğü, 2014. Ankara Şube Müdürlüğü korunan alanlar dosyaları. Ankara.

OSB IX. Bölge Müdürlüğü, 2016. Ankara Şube Müdürlüğü web sayfası. http://bolge9.ormansu.gov.tr (Ziyaret Tarihi: 01.10.2016).

Ortaçeşme, V., Özkan, B., Karagüzel, O., 2002. An Estimation the, Recreation Use Value Of Kursunlu Waterfall Nature Park by the Individual Travel Cost Method. Turk J Agric For, 26, pp.57-62.

Özdemir, E., 2006. Çevre Sorunlarının Ekonomik Niteliği Bağlamında Dışsallıkların Ortadan Kaldırılması. Ankara Üniversitesi Sosyal Bilimler Enstitüsü, Yüksek Lisans Tezi, Ankara. $151 \mathrm{~s}$.

Pak, M., 2003. Orman Kaynağından Rekreasyon Amaçlı Yararlanmanın Ekonomik Değerinin Tahmin Edilmesi ve $\mathrm{Bu}$ Değer Üzerinde Etkili Olan Değişkenler Üzerine Bir Araștırma (Doğu Akdeniz ve Doğu Karadeniz Bölgesi Orman İçi Dinlenme Yerleri Örneği), (Doktora Tezi) Karadeniz Teknik Üniversitesi Fen Bilimleri Ens- titüsü, Trabzon.

Pearce, D., 2002. An intellectual history of environmental economics. Annual Review of Energy and the Environment $27,57-81$.

Piper, S., 1997. Regional impacts and benefits of waterbased activities: An application in the Black Hills region of South Dakota and Wyoming. Impact Assessment 15: 335-359.

Shalloof, F.M., 1985. Impact of various factors upon benefits from big game hunting estimated by the travel cost method. PhD dissertation. Corvallis, OR: Oregon State University.

TÜİK, 2016. Tüketici Fiyatları Endeksi. http://www. tuik.gov.tr (Ziyaret Tarihi: 03.10.2016).

Sutherland, W. J., 1983. Aggregation and the "ideal free" distribution. Journal of Animal Ecology, 52:821-828.

Yazıcıŏlu, Y., Erdoğan, S., 2004. SPSS Uygulamalı Bilimsel Araştırma Yöntemleri. Detay Yayıncılık, Ankara.

Ward, F. A., Roach, B., A., Ready, R. C., Henderson, J. E., 1996. Regional Recreation Demand Models for Large Reservoirs: Database Development, Model Estimation, and Management Applications. Final report to U.S. Army Corps of Engineers 